高分子㖮文集 (Kobunshi Ronbunshu), Vol. 44, No. 12, pp. 885-891 (Dec., 1987)

\title{
多孔性セルロース微粒子をマトリックスとした薬物徐放性製戍の調製*
}

\author{
細井 文雄*1・齋藤 健司*2・幕内 恵三*1 ・ 小石 真純*2
}

（受付 1987 年 3 月 12 日・蕃查終了1 987 年 5 月 7 日)

\begin{abstract}
要 旨 セルロースを主成分とする多孔性枚柆子に $\gamma$ 線前照射法でメタクリル酸メチル(MMA)をグラフト重

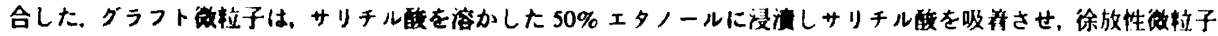

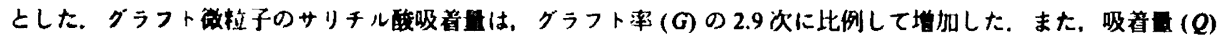

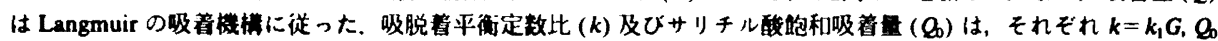
$=k_{2} G$ で表された。 ここで、nは2.4であり，吸着サイトはクラフト革の $n$ 次に比例して生成することかかかった。 これらの䊅果から、サリチル聵はクラフトポリマーに吸着されるのではなく、グラフトポリマーとセルロースとの 相互作用によって生成する昅音サイトに捕隻されることが明らかになった．同様な結果か，サリチル酸存在下で MMA，MMA-スチレン (St)，MMAーメタクリル酸 (MAc)などをグラフトさせて得た徐放性微粒子でも確認され た。吸着サイトの生成数、吸着サイト間の相互作用やグラフトポリマー（吸着サイト）と蒋物の相互作用の大きさ

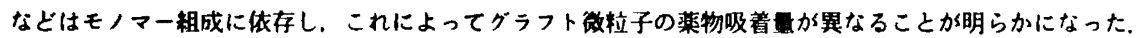

\section{1 粕喜}

薬効の持続性の改良や菜物による副作用の低減を目的 として，徐放性製郕に関する研究が幅広く行われてい

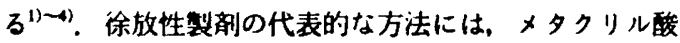

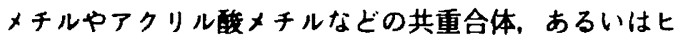
ドロゲルのような多孔性構造をるつ高分子中に薬物を分 散させるマトリックス法と、莱物を一定の厚みの膜で被 嘚するメンフラン法とがある゙．

マトリックス法には薬物を溶かした高分子膨㵎溶媒に 高分子を浸清させる浸清法と，薬物とモノマーを混合し 重合させる万法がある。浸漬法では，一般にヒドロゲル が用いられているか，水に対する膨潤度か大きく溶出速 度も速いので長期間の徐放化には適さない，また，膨潤 によるマトリックスの強度低下も大きい，このため，橋 かけや合成ヒドロゲルによる溶出速度の制御が試みられ ている(6) 10). 一方, 重合法はマトリックス中の薬物浱度 を高めることができるが、薬物の熱による変質や，重合 開始郕が混入する可能性がある。放射線重合法は低温で 重合ができ，開始郕も必要としないのでこれらの問題を 回避できる. しかし，低線国の照射によって薬物の生理 的活性度か落ちるという報告すある゙11.

\footnotetext{
*本辄を「多孔性微粒子を用いた薬物含有カブセルの調製 第 5 報」とする。

*1 日本原子力研究所高崎研究所 $(370-12$ 高崎市綿贯町 1233 番地)

* 東京理科大学薬学部（8162 新宿区市っ谷船河原町12番地）
}

このような観点から，著者らは薬物担体としてセル ロースを主成分とする機械的强度に優れた多孔性微粒子 の利用を考え，あらかじめ $\gamma$ 線を照射した多孔性微粒子 に薬物存在下で各種モ/マーをグラフト重合させ，徐放 性微粒子の調製を試みだ2) 15)，前報ではグラフト率の 增加に従って微粒子の薬物吸着量加指数関数的に增加す ることを明らかにした ${ }^{15)}$. しかし，吸着量はモノマーに 溶けていた薬物がそのままポリマーに包括されるとした ときの値よりも小さく，重合と薬物の吸着とはそれぞれ 別々に起こっていると示唆された。

本報告では，グラフト微粒子の菓物吸着機構を明らか にするため，モデル薬物としてサリチル酸を使用し、サ リチル酸存在下及び非存在下でメタクリル酸メチルある いはスチレンやメタクリル酸とメタクリル酸メチルの混 合物をグラフト重分させた。サリチル酸非存在下でグラ フトした微柆子は，浸清法でサリチル酸を吸着させ徐放 性微粒子とした。これらの微粒子のサリチル酸吸着量及 びサリチル酸溶出速度について検討し、グラフト微柆子 の薬物吸着機構について考察した。

\section{2 実敦方法}

\section{1 試料}

多孔性微粒子はセルロースを素材とした真球状微粒子 セルロファイン GC-700 m (平均乾燥粒子径 $39.4 \mu \mathrm{m}$, 排 除限界分子量 70000、チッン(株)製）を脱水乾燥して使 用した。サリチル酸及びメタクリル酸メチル (MMA), メタクリル酸 (MAc), スチレン (St) は市販の試薬特級 
細井・㾞藤・幕内・小石

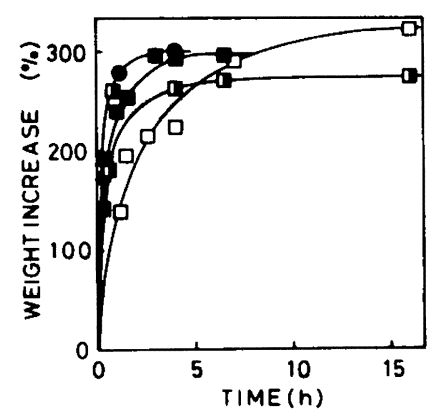

Fig. 1. Weight increase of porous spheres by graft polymerization. Without salicylic acid: O, MMA. With salicylic acid: D, MMA; D, MMA-MAc (9:1); $\square$, MMA-St $(9: 1)$

\section{をそのまま使用した}

\section{2 前照射法及ひ徐放性㪀粒子調筡法}

グラフト重合による徐放性微粒子の調製は，放射線に よるサリチル酸の分解を防ぐため前照射法で行った，所 定量のセルロファインをコック付きガラスアンプルに入 れ、内圧が $10^{-3}$ Torrになるまで吸引した。 アンプルを -78 ${ }^{\circ} \mathrm{C}$ の温度まで邻した後, ${ }^{\infty 0} \mathrm{Co}$ からの $\gamma$ 線を線量深 $20 \mathrm{kGy} / \mathrm{h}$ で $60 \mathrm{kGy}$ 照射した.

これとは別に, フレーカフルシール付きアンプルにセ ルロファイン $1 \mathrm{~g}$ 当たりサリチル酸 $0.3 \mathrm{~g}$. 蒸留水 $1.5 \mathrm{~g}$. エタノール0.5 g, モノマー $3.7 \mathrm{~g}$ をれた。 アンプルは 凍結及び吸引を 4 回繰り返し, 溶存空気を除いてから封 管した，照射したアンブルは， $-78^{\circ} \mathrm{C}$ に保持し窒素気流 中でモノマー溶液の入ったアンプルと接続した。 その 後, 圧力が $10^{-5}$ Torrになるまで吸引した。次に, 室温で フレーカフルシールを破り、モノマー液を多孔性微粒子 の入ったアンブルに筫入した，グラフト重合は $40^{\circ} \mathrm{C} て ゙$

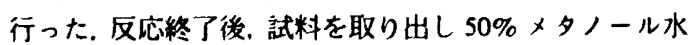
溶洨 $20 \mathrm{ml}$ で 5 回洗浄し未反応モ/マー及び未吸着サリ チル酸を除去した。試料は真空乾嬠器にいれ, 重战が二 定になるまで室温で減圧乾燥した。

浸漬法による徐放性微粒子の調製は，まずサリチル酸 を除く蒸留水、エタノール，及びモノマーがそれぞれ上 述した割合の混合溶液を調彆し，上述した操作と同じ方 法でセルロファインにグラフト重合させた，反応終了 後, 試料を取り出し $20 \mathrm{~m} /$ のタノールで 5 回洗浄し未 反応モノマーを除いた。 グラフト微粒子は重量が一定に なるまで室温で咸圧乾燥した。次にフレーカフルシール 付き $\mathrm{H}$ 型アンプルの一方に所定量のグラフト微粒子を いれ，10“Torr まで脱気し封管した．他方のアンプルに はグラフト試料 $1 \mathrm{~g}$ 当たり $8 \mathrm{ml}$ の $50 \%$ エタノール水溶 液之所定量のサリチル酸をいれ，溶存空気を除いてから 封管した。サリチル酸の添加量は，漕度が 12.5 から 125

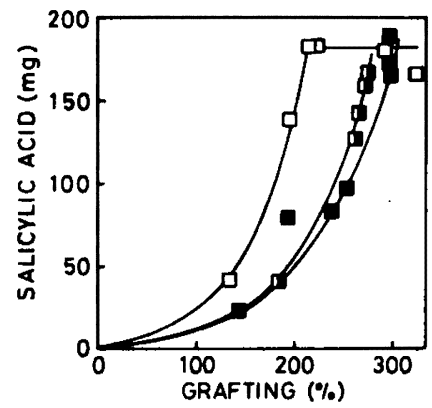

Fig. 2. The amount of salicylic acid released from the spheres modified by grafting of various monomers in the presence of salicylic acid: $\mathbf{D}, \mathbf{M M A} \mathbf{D}, \mathbf{M M A}-$ MAc (9:1); $\square$, MMA-St (9:1).

$\mathrm{mg} / \mathrm{m} /$ になるよう調製した. グラフト微粒子へのサリチ ル酸の含浸は、フレーカフルシールを破りサリチル酸溶 液を微粒子の入ったアンブルに導入してから, $40^{\circ} \mathrm{C}$ の温 度で 16 時間放置して行った. 放置後, 試料をガラスフィ ルターにあけ過剩な溶液を除いたのち、 $50 \%$ メタール 水溶液 $20 \mathrm{~m} /$ で 5 回洗浄し, 粒子表面に残っているフ リーなサリチル酸を除去した．含浸試料は真空乾燥器に いれ，重韽が一定になるまで室温で咸圧乾燥した。

吸着崖の測定は，サリチル酸の水に対する溶解度が著 しく小さい $\left(0.4 \mathrm{~g} / 100 \mathrm{ml}, 40^{\circ} \mathrm{C}\right)$ ので，吸着量を正確に 求めるため $80 \%$ メタール水溶液を使用した。 $50 \%$ メ

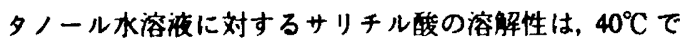
$6.2 \mathrm{~g} / 100 \mathrm{ml}$ であった，測定は，柴外分光光度計 ((株)島 津製作所製，UV-240）を用いて行った。およそ $3 \mathrm{mg} の$ 試料をかくはん子に付属した 300 メッシュのステンレス スチール紫バスケットに正確に科量し， $3 \mathrm{~m} /$ の $50 \%$ メ

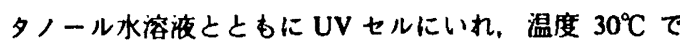
かくはんしながら一定時間ごとに $296.7 \mathrm{~nm}$ の吸光度を 測定した。

サリチル酸の溶出速度は，pH 1.2 の塩酸を使用し上述 した操作と同じ方法により, $299.6 \mathrm{~nm}$ の吸光度を測定し た.

\section{3 结果と考察}

3.1 前照射法によるビニルモノマーのクラフト重合 照射做粒子とモ/マー浴液を接触させると粒子は膨淍 し、モノマー溶液は粒子内に吸収され、重合か開始した。 一方, モ/マー溶液にセルロースの膨潤溶媒の水を添加 しないと粒子の膨潤は起こらず，重合むほとんど起こら なかった。この事実から、グラフト文応はほとんど粒子 内で起こると推定された。

Fig. 1 には，反応時間とグラフト微粒子の重量增加率 との関係を示した，重量增加率はいずれの場合も反応時 


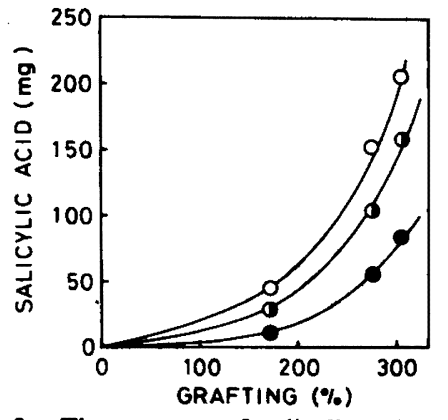

Fig. 3. The amount of salicylic acid adsorbed by immersing the modified spheres by grafting MMA in a $50 \%$ aqueous ethanol solution containing salicylic acid. Salicylic acid concentration: $0,125 \mathrm{mg} / \mathrm{m}$;, $37.5 \mathrm{mg} / \mathrm{ml}, 0,12.5 \mathrm{mg} / \mathrm{ml}$.

間とともに增加し，4から16時間で一定値になった. 重 田增加の程度はモノマー組成によって異なり，またサ リチル酸存在下では非存在下のそれと比べいぶん低く なった.

\section{2 サリチル酸存在下でグラフトした砤柆子のサリ チル酸吸静}

末グラフト徽粒子はサリチル酸に対し，吸着能力をほ とんど示さなかった. Fig. 2 には、サリチル酸存在下で グラフトした啟柆子から溶出したサリチル酸量とグラフ ト率との関係を示した。なお，溶出量は未クラフト柆子 $1 \mathrm{~g}$ 当たりに換算した值である. Fig. 2 では，溶出溶媒と して 50\%メタノール水溶液を使用した，溶出溶媒をメ タノールに変えても同じ結果が得られた。 サリチル酸の 50\%×タノール水溶液及びメタノールに対する溶解度 は， $40^{\circ} \mathrm{C}$ でそれぞれ 6.2 及び $31.7 \mathrm{~g} / 100 \mathrm{ml}$ であった。こ の結果は、グラフト微粒子に吸着したサリチル酸はすべ て50\%メタノール水溶液に溶出することを示している. ここでは, 50\%メタノール水溶液における溶出量をグラ フト微粒子のサリチル酸吸着量とした。

吸着量は，グラフト率の 2.7 次から 3.4 次に比例して 增加した。 その增加の程度は St-MMA(モル比 1:9)> MAc-MMA(モル比 1:9)>MMA の順となり， MMA にサリチル酸と同じ構造をもつモノマーを添加すると吸 着量が増大した。 しかし、St-MMA 系ではグラフト率が 200\%以上になると, 吸着县は一定になった. Fig. 2 に示 した吸着量は，どのグラフト学においても，モノマーに 溶けていたサリチル酸がそのままポリマーに包括される としたときの値よりあ小さい.これらの結果から，グラ フト重合とサリチル酸の吸着とはそれぞれ別々に起こっ ていると考え，サリチル酸非存在下でグラフトした微粒 子を用いて，浸清法によるサリチル酸含有微粒子の調製 を試みた。

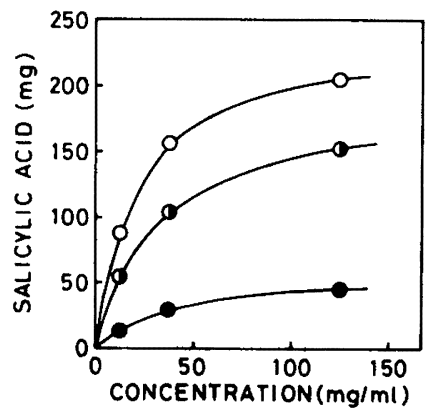

Fig. 4. Effect of salicylic acid concentration on the amount of salicylic acid adsorbed. Percent grafting of MMA: $0,306.5 \%: 0,276.7 \%$ : $0,173.3 \%$.

\section{3 漫淇法による徐放性微粒子の略等}

グラフト微粒子へのサリチル酸の含浸は, サリチル酸 を溶かした50\%エタノール水溶液にグラフト微粒子を 浸清して行った。.Fig. 3 には，グラフト微粒子を種々の 浱度のサリチル酸溶液に浸漬したときのサリチル酸吸着 鱼とグラフト率との関係を示した。綎朝の吸着量は，末 グラフト粒子 $1 \mathrm{~g}$ がグラフト改質によって吸着するサリ チル酸量を表す. 吸着量は，Fig. 2 の結果と同様に、グラ ト率の 2.9 次に比例して增加した. この結果からサリチ ル酸存在下でグラフトしたときも、グラフト反応とサリ チル酸の吸着とはそれぞれ別々に起こることがわかっ た. なお、サリチル酸がグラフトポリマー中に分散する ならば，吸着量はグラフト率の増加に伴って直線的に增 加するはずである. Fig. 3 の結果は, グラフトポリマー とセルロースとの相互作用によってサリチル酸が粒子内 に吸着されることを示していると考えられる.

Fig. 4 は50\%エ夕ノール水溶液のサリチル酸浱度之 グラフト粒子のサリチル酸吸着量との関係を示した．吸 着量はサリチル酸湄度の增加とともに上に凸の曲線を与 え，飽和値に達する傾向を示した。

一般に、活性炭やシリカゲルなどの多孔性吸着媒では 表面の性質が不均一であるため，吸着量は濃度の $1 / n$ 乗 に比例して增加する ${ }^{16)}$. また, 被後率の增加に伴って吸 着熱が低下する場合も，吸着量は濯度の $1 / n$ 乗に比例す ろ. Fig. 4 に示した吸着救とサリチル酸濃度の関係につ いて而対数プロットを試みたが, 直線関係は得られな かった. そこで,

（1）グラフト重合の進行に伴って、粒子内部に均一に 吸着サイトが生成する,

（2）吸着サイトに捕狽された薬物分子は近くのサイト に別の薬物分子が吸着するのに影響を及ぼさな い.

（3）各サイトには薬物分子が 1 個しか捕獾されない, と仮定して，次のような Langmuir 吸着等温式を誘莧し 


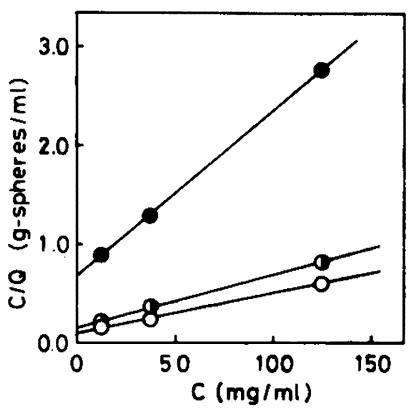

Fig. 5. Plots of $C / Q$ vs. salicylic acid concentration (C). The symbols are the same as those in Fig. 4.

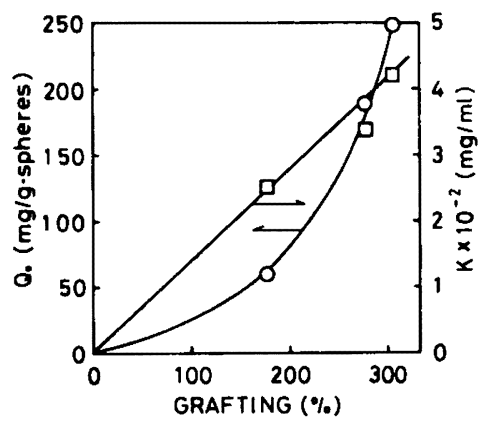

Fig. 6. The effect of grafting on the saturated amount of salicylic acid adsorbed and the ratio of equilibrium constants for adsorption and desorption. た

$$
C / Q=1 / k Q_{0}+C / Q_{0}
$$

ここで，Cは50\%エ夕/ール水溶液のサリチル酸浱度 $(\mathrm{mg} / \mathrm{m}), Q$ は元の粒子 $1 \mathrm{~g}$ 当たりに換算したグラフト

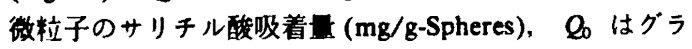
フト微柆子のサリチル酸的和吸着量 (mg/g-Spheres), $k$ は吸脱着の平衡定数比である.

Fig. 5 には式（1）に従い、サリチル酸嶩度 Cに対し $C / Q を フ ゚ ロ ッ ト し た ， C / Q$ と $C$ との間には直線関係が成 立することから、グラフト微粒子に対するサリチル酸の 吸着は, Langmuir の吸着機檋に従うことがわかった。

Fig. 5 におけるこう配は $1 / k Q_{0}$ を、維軸の切片は $1 / Q_{0}$ を 表す. Fig. 6 にはグラフト率と $k$ 及び $Q_{0}$ との関係を示し た. 盷和吸着量はグラフト率の 2.4 次に比例して增加し た。粒子内で重合した PMMA 中に吸着サイトが生成す るならは，飽和吸着量はグラフト率に比例して增加す ろ. Gayloadは, MMAのような電子供与性のモノマー はカルボニル基を通してセルロースとコンプレックスを つくると報告している(1)，粒子内で重合が起こるとグラ フトポリマーとセルロースとの接触界面は增加する，飽 和吸着量の増加は，これら両者の相互作用によって，吸

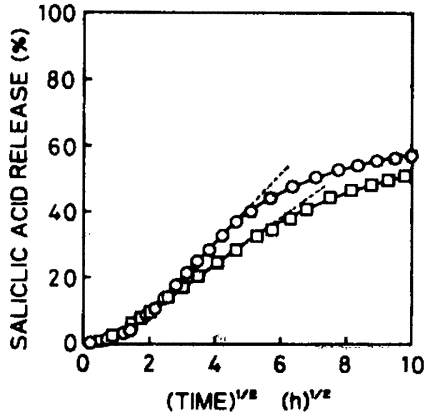

Fig. 7. Release profiles of salicylic acid from spheres modified by grafting MMA in aq. $\mathrm{HCl}$ (pH 1.2). the spheres were obtained by grafting in the presence of salicylic acid; $O$, the spheres were obtained by the dipping method.

着サイトがグラフト率の 2.4 次に比例して生成すること を示している。なお、グラフト深が $306 \%$ になると盷和 吸着量は $248 \mathrm{mg}$ まで增加した。

一方、吸着平衡定数比はグラフト率の增加とともに直 線的に增加した。これは、クラフト率が增加するとサリ チル酸が吸着しやすくなることを示している。一般に, 吸着汃進み被得落加增大すると，吸着質間の相互作用に よって吸着熱が低下し，吸着がより起こりやすくな $3^{16)}$. しかし，この系では， $C / Q$ と $C$ との間に直線関倸 が成り立つことから (Fig. 5), 吸着熱は被復率によらず 一定である.グラフトポリマーとセルロースの相互作用 は, グラフト率の增加に伴って增加する. 吸脱着定数比 の增加は、これに伴う吸着サイト間の相互作用の增加に よると思われる.

\section{4 グラフト做柆子からのサリチル酸の溶出}

サリチル酸存在下でグラフトした微粒子及び浸清法で サリチル酸を吸着させた微粒子のサリチル酸溶出挙動 を、 $\mathrm{pH} 1.2$ の塩酸を用いて検討した。 サリチル酸は時間 とともに溶出し，およそ144時間で一定量に達した。こ れは50\%メタノール水洨液を用いたときに比へ，およ そ40 倍ほど長かった。 また，溶出量す50\%メタノール 水溶液のおよそ70\%であった。

Fig. 7 にサリチル酸存在下でグラフトした微粒子及び 浸清法でサリチル酸を吸着したグラフト微粒子から溶出 したサリチル酸の割合と溶出時間の $1 / 2$ 乗との関係を示 した，いずれの場合す溶出率 $40 \%$ までは, 雨者の間に直 線関係が得られた。 マトリックス中に分子状に溶解した 薬物の拡散が、マトリックスの多孔性度や溶出経路の曲 がり度に影害を受けるとき, 溶出速度式は次式で表され $3^{(9), 20)}$.

$$
Q^{\prime} / Q=6(\varepsilon / r)\left(D_{i w} / \tau \pi\right)^{1 / 2} t^{1 / 2}
$$

ここで， $Q^{\prime}$ は時間 $t$ までに溶出した薬物量， $Q$ は試料に 


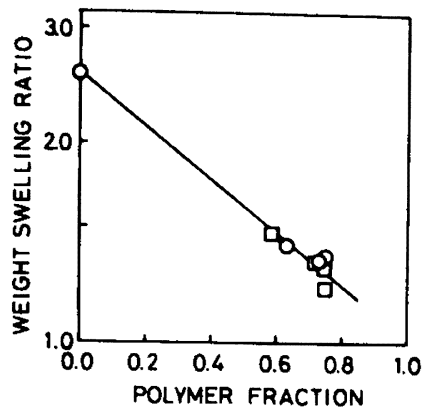

Fig. 8. Effect of fractional weight of graft polymer in modified spheres (polymer fraction) on the weight swelling ratio of spheres. The symbols are the same as those in Fig. 7.

吸着された楽物量、「は膨淍粒子径、ては溶出経路の曲が り度を表す。また, $\varepsilon$ はマトリックスの多孔性度であり。 近似的には粒子を溶出液に浸清したときの重量脚澗比で

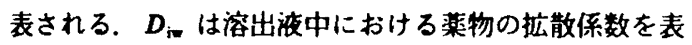
す.

Fig. 8 には, pH 1.2 の塩酸にグラフト微柆子を浸漬し たときの重量膨閔比と粒子中の MMA ポリマーの重量 分率（ポリマーフラクション）との関係を示した。グラ フト微粒子の多孔性度は, MMA ポリマーの重量分率の 增加とともに直線的に減少した。 また，同じポリマーフ ラクションでは、サリチル酸存在下及び非存在下でグラ フトした粒子のどちらす同じ多孔性度を示した。

Fig. 9 には, 溶出百分率と $t^{1 / 2}$ 乗とのプロットで得ら れる直線のこう目の値に、グラフト微粒子を溶出液に浸

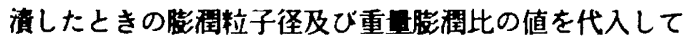
求めた $6\left(D_{\mathrm{iw}} / \tau \pi\right)^{1 / 2}$ とポリマーフラクションとの用係を 示した. $6\left(D_{\mathrm{w} w} / \tau \pi\right)^{1 / 2}$ の值はポリマーフラクションが增 加するに従って低下した。これは，溶出速度がクラフト 率の增加とともに低下することを示している．D到は粒 子の空孔を満たしている溶出液中での薬物の拡散定数で あるから、グラフト率に依存しないと考えられる.した がって，この低下はグラフト事の增加に伴うての增加に よると思われる.これは重合に伴ってグラフトボリマー 鎖とセルロース分子鎖との絡み合いやグラフトポリマー

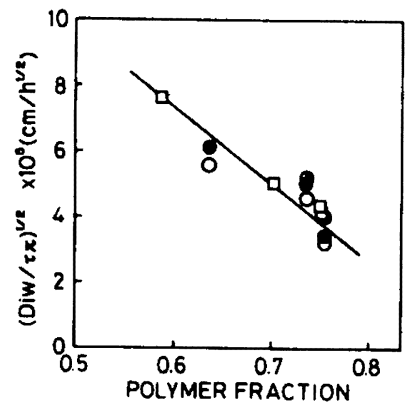

Fig. 9. Dependency of $\left(D_{i w} / \tau \pi\right)^{1 / 2}$ on the polymer fraction in modified spheres. The spheres were obtained by grafting of MMA in the presence of salicylic acid, $\square$. The spheres were obtained by dipping in a $50 \%$ aqueous ethanol solution containing salicylic acid: $\bigcirc, 125 \mathrm{mg} / \mathrm{ml} ; 0,37.5 \mathrm{mg} / \mathrm{ml} ; \bullet, 12.5 \mathrm{mg} / \mathrm{ml}$.

鎖同士の絡み合いが増加するからであろう.

なお，ポリマーフラクションが同じ場合、サリチル酸 存在下でグラフトした微粒子及び浸漬法でサリチル酸を 吸着させた微粒子の $6\left(D_{\mathrm{iw}} / \tau \pi\right)^{1 / 2}$ は，はほ同じ値を示し た.

\section{5 グラフト砤粒子のサリチル酸吸着量に対するモ ノマー組成の影雪}

Fig. 1, 2, 及び 5 の結果から、サリチル酸存在下でグラ フト重合したときも重合に伴って薬物吸着サイトが生成 し、これにサリチル酸が吸着することがわかった. Fig. 6 の結果から, 式 (1)のk及び $Q_{0}$ はそれぞれ，k=k, $G, Q_{0}$ $=k_{2} G^{n}$ で表される。 ここで $G$ はグラフト率， $k_{1}$ 及び $k_{2}$ は定数である.したがって, 式（1）は次式のように㫪き 改められる。

$$
C / Q=\left(1 / k_{1} k_{2} G^{(n+1)}\right)+\left(C / k_{2} G^{n}\right)
$$

式（3）において, $n$ は重合に伴う吸着サイトの生成のし やすさを， $k_{1}$ は生成した吸着サイト間の相互作用の大き さを， $k_{2}$ は薬物と吸着サイト間の相互作用の大きさをそ れぞれ表す．Fig. 1 から明らかなように，グラフト微粒 子のサリチル酸吸着量はモノマーの種類によって著しく 変化する. Fig.1の結果をむとに, 式 (3) からサリチル 酸存在下でグラフトした微粒子の $k_{1}, k_{2}$, 及び $n$ を非線

Table 1. Effect of monomer compositions on the values of constants in eq. (3)

\begin{tabular}{lccccc}
\hline $\begin{array}{c}\text { Monomer } \\
\text { composition }\end{array}$ & $\begin{array}{c}k_{1} \\
(\mathrm{mg} / \mathrm{m} /)\end{array}$ & $\begin{array}{c}k_{2} \\
(\mathrm{mg} / \mathrm{g} \text {-spheres })\end{array}$ & $n$ & $\begin{array}{c}\left.k^{*}\right) \\
(\mathrm{mg} / \mathrm{m} /)\end{array}$ & $\begin{array}{c}\left.Q_{0}{ }^{\circ}\right) \\
(\mathrm{mg} / \mathrm{g} \text {-spheres })\end{array}$ \\
\hline MMA & 2.697 & 0.040 & 1.64 & 5.39 & 126.0 \\
MMA-MAc $(9: 1)$ & 5.145 & 0.017 & 2.41 & 10.29 & 91.8 \\
MMA-St $(9: 1)$ & 3.196 & 0.080 & 2.00 & 6.39 & 322.9 \\
\hline
\end{tabular}

c) The values of $k$ and $Q_{0}$ are calculated at $200 \%$ grafting. 
型最小二乗法で算出し ${ }^{21 !}$ ，飽和吸着量及びサリチル酸吸 脱着平衡定数比に対するモノマー組成の影凘を検討し た. Table 1 に結果を示した. MMAにStを添加した系 では，吸着サイト間の相互作用の大きさは変わらない が、吸着サイトの生成数加增加し、薬物之吸着サイトの 相互作用か增加するため，吸着量が著しく增加する．StMMA グラフト微粒子の溶出中における膨瀾粒子径及び 重量膨潤比は共に, MMA グラフト微粒子のそれよりも 小さくなる. St 添加系では, グラフトポリマーの親水性 が低下し、グラフトポリマーとセルロースとの絡み合い が增加するため、吸着サイトの数が增加すると考えられ ろ.

MAc 添加系では，吸着サイトの数が增加するととも に, 吸着サイト間の相互作用の增加によってサリチル酸 が吸着しやすくなる。しかし，吸着サイト薬物間の相互 作用が低下するため, 結果として吸着量の增加が St 添 加系より 㧕えられる。相互作用の低下は, 吸着サイト とサリチル酸のカルボキシル基同士の電荷的反発による ものであろう.

\section{4 結論}

セルロースを主成分とする多孔性微粒子にあらかじめ $\gamma$ 線を照射した後、サリチル酸存在下でMMA 及び MMA-St, MMA-MAcをグラフト重合し, 徐放性微粒 子の調製を試みた。同様に、サリチル酸非存在下で MMAをグラフトした微粒子をサリチル酸の $50 \%$ エ ノール水溶液に浸清し、徐放性微粒子を調製した。元の 馓粒子はサリチル酸をほとんど吸着しないが、グラフト 微柆子はサリチル酸を吸着した徐放性微柆子となった。 グラフト微粒子のサリチル酸吸着量は，いずれの場合も グラフト辛の $n$ 次に比例して $(n>1)$ 增加した。 これは,

(1) グラフトポリマーとセルロースの相互作用によ り、グラフト率の $n$ 次に比例して蝶物吸着サイト が生成する。

（2）グラフト率が增加すると吸着サイト間の相互作用 が大きくなり、サリチル酸が吸着しやすくなる， ためと考えられた。

MMA にStやMAcを添加すると、グラフト微粒子の サリチル酸吸着量が增加した。これは, StやMAcを添 加すると吸着サイトの生成量, 吸着サイト間の相互作用
の大きさ、グラフトポリマー（吸着サイト）と薬物の相 互作用の大きさなどか変化するためと考えられた。

これらの結果は，グラフトポリマーの構造を変えるこ とによって，グラフト微粒子に種々の楽物を効率よく吸 着できることを示している.

\section{文献}

1) 近藤朝士、“マイクロカブセル”, 日刊工業新聞社, 東京 (1971).

2）熹悦 㠫, ・コントロールリリースの実隐”、シーエム シー, 東京 (1985), p. 191.

3) J. S. Kent, "Controlled Released Polymeric Formulations", American Chemical Society, Washington, D. C. (1976), pp. 157-170.

4) J. Folkman and D. M. Long, Ann, N. Y. Acad. Sci, 111, 857 (1964).

5) 従二和彦，中野公帆，化学工業，39，288 (1986).

6) 平野櫂三，眼下踄休医報，69, 204 (1975).

7) 保坂俊太郎, 村尾康雄, 中川裕子, 膜, 5, 377 (1980).

8) 保坂俊太郎, 丹沢 宏。小沢均, 村尾康雄, 国友哲之輔, 高分子詥文集，39，277 (1982).

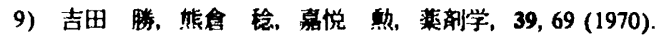

10) R. Gurny, E. Doelker, and N. A. Papas, Biomaterials, 3, 27 (1982).

11) G. P. Jacobs, Radiat. Phys. Chem., 26, 133 (1985).

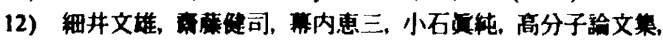
42, 415 (1985).

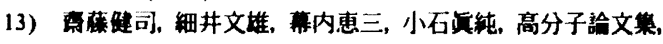
43, 51 (1986).

14) K. Saito, F. Hosoi, K. Makuuchi and M. Koishi, Chem. Pharm. Bull., 35, 2045 (1987).

15) K. Saito, F. Hosoi, K. Makuuchi, and M. Koishi, 蒋剂学. 47, 154 (1987).

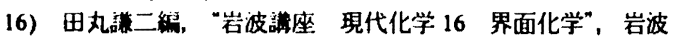
意店, 東京 (1980), p. 84.

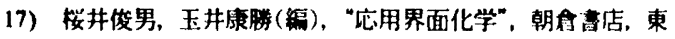
京 (1972), p. 179.

18) Gayload, J. Polym. Sci, 37, 153 (1972).

19) S. J. Desai, A. P. Simonelli, and W. I. Higuchi, J. Pharm. Sci., 51, 1459 (1962).

20) S. J. Desai, A. P. Simonelli, and W. I. Higuchi, J. Pharm. Sci., 55, 1224 (1966).

21）田中善正, 山岡 清, “化学者のためのマイコンガイド", 南江堂, 東京 (1982), p. 114. 


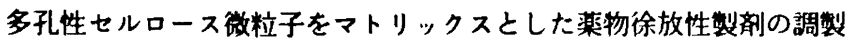

A Sustained Release System Using Porous Cellulose Spheres Modified by Grafting as Matrices* Fumio Hosol*1, Kenji SaITo*2, Keizou MaKuUCHI*1, and Masumi Kolshi*2 *Preparation of Capsules Containing Drug with Porous Particles V.

*1 Takasaki Radiation Chemistry Research Establishment, Japan Atomic Energy Research Institute (1233 Watanukimachi, Takasaki, Gunma, 370-12 Japan)

*2 Faculty of Pharmaceutical Science, Science University of Tokyo (12 Ichigaya Funagawara, Shinjuku, Tokyo, 162 Japan)

Polymer-coated spheres, obtained by the graft polymerization of methyl methacrylate (MMA) onto porous spheres based on cellulose by the pre-irradiation method, were used as matrices for the drug sustained release system for salicylic acid. The adsorption of salicylic acid was carried out by dipping the grafted spheres in a $50 \%$ aqueous ethanol solution containing salicylic acid. The amount of salicylic acid adsorbed $(Q)$ increased proportionately with the percent graft of MMA (G) to the power of 2.9. Adsorption mechanism of salicylic acid could be expressed in term of Langmuir's adsorption isotherm. The ratio of constants for adsorption and desorption $(k)$ and the saturated amount of salicylic acid adsorbed $\left(Q_{0}\right)$ were expressed as $k=k_{1} G$ and $Q_{0}=k_{2} G^{24}$, respectively. These results indicate that the number of adsorption sites increased proportionately with the $n$th power of $G$ as a results of the interaction of grafted poly (methyl methacrylate) (PMMA) and cellulose. Similar results were obtained with grafting of MMA, MMA-styrene (St), and MMA-methacrylic acid (MAc) in the presence of salicylic acid.

KEY WORDS Sustained Release System / Controlled Release System / Salicylic Acid / Porous Spheres / Modified

Cellulose Spheres / Graft Polymerization / Methyl Methacrylate / Pre-Irradiation / $\gamma$-Ray /

(Received March 12, 1987: Accepted May 7, 1987)

[Kobunshi Ronbunshu, 44(12), 885-891 (1987)] 